\title{
Karyotypic variation of Glanidium ribeiroi Haseman, 1911 (Siluriformes, Auchenipteridae) along the Iguazu river basin
}

\author{
R. L. Lui ${ }^{\text {* }}$, D. R. Blanco ${ }^{b}$, J. B. Traldic, V. P. Margarido a and O. Moreira-Filho ${ }^{c}$ \\ aLaboratório de Genética, Centro de Ciências Biológicas e da Saúde, Universidade Estadual do Oeste do \\ Paraná - UNIOESTE, Rua Universitária, 2069, CEP 85819-110, Cascavel, PR, Brazil \\ ${ }^{b}$ Universidade Tecnológica Federal do Paraná - UTFPR, Prolongamento da Rua Cerejeira, s/n, \\ CEP 85892-000, Santa Helena, PR, Brazil \\ 'Departamento de Genética e Evolução, Universidade Federal de São Carlos - UFSCar, \\ Rodovia Washington Luís, Km 235, CEP 13565-905, São Carlos, SP, Brazil \\ *e-mail: roberto.lui@unioeste.br
}

Received: June 2, 2014 - Accepted: August 4, 2014 - Distributed: November 30, 2015

(With 3 figures)

\begin{abstract}
The Iguazu river is a tributary of the left margin of the Paraná river, isolated from this basin about 22 million years ago with the appearance of the Iguazu Falls. The Iguazu river is characterized by high endemism due to two factors: its rugged topography and the old isolation caused by formation of the Iguazu Falls. This study analyzed cytogenetically a population of Glanidium ribeiroi collected in a region at the final stretch of this basin, by Giemsa staining, C-banding, impregnation by silver nitrate, and FISH with probes of $5 \mathrm{~S}$ rDNA, $18 \mathrm{~S}$ rDNA, telomeric sequence $[\text { TTAGGG }]_{\mathrm{n}}$, and $[\mathrm{GATA}]_{\mathrm{n}}$ repeats. The diploid number was equal to 58 chromosomes. The heterochromatin was present in the terminal region of almost all chromosomes. The Ag-NORs were simple and presented interstitially on the short arm of the submetacentric pair 14, which was confirmed by FISH with $18 \mathrm{~S}$ rDNA probe. The 5S rDNA-FISH marked only the submetacentric pair 16 on the long arm in interstitial position. The FISH with [TTAGGG] ${ }_{\mathrm{n}}$ probe presented all telomeres labeled as expected, with an absence of Interstitial Telomeric Sequence (ITS). The repetitive [GATA $]_{n}$ sequence was dispersed throughout the genome, with preferential location in the terminal region of all chromosomes. The data obtained are discussed herein with other species of Auchenipteridae, and other previously analyzed populations of G. ribeiroi from the Iguazu river, verifying differences among these populations, which should be mainly related to the rugged topography of this basin.
\end{abstract}

Keywords: geographical barriers, ribosomal DNA, Glanidium ribeiroi, Iguazu river.

\section{Variação cariotípica de Glanidium ribeiroi Haseman, 1911 (Siluriformes, Auchenipteridae) ao longo da bacia do rio Iguaçu}

\begin{abstract}
Resumo
O rio Iguaçu é um afluente da margem esquerda do rio Paraná, que foi separado desta bacia a aproximadamente 22 milhões de anos com o surgimento das Cataratas do Iguaçu. Esse rio é caracterizado por elevado endemismo, o que se deve a dois fatores: sua acidentada topografia e ao antigo isolamento proporcionado pela formação das cataratas. No presente trabalho foi analisado cromossomicamente uma população de Glanidium ribeiroi coletada em uma região que corresponde ao trecho final desse rio, através de coloração com Giemsa, bandamento-C, impregnação pelo nitrato de prata e FISH com sondas de rDNA 5S, rDNA 18S, sequência telomérica [TTAGGG] $]_{n}$ e repetições $[\mathrm{GATA}]_{\mathrm{n}}$. O número diploide encontrado foi igual a 58 cromossomos. A heterocromatina se mostrou dispersa na região terminal de quase todos os cromossomos. As Ag-RONs são simples e presentes no braço curto em posição intersticial do par submetacêntrico 14, o que foi confirmado pela FISH com rDNA 18S. O rDNA 5S marcou apenas o par submetacêntrico 16 no braço longo em posição intersticial. A hibridização com sonda [TTAGGG] $]_{n}$ revelou todos os telômeros marcados conforme esperado e ausência de Sequência Telomérica Intersticial (ITS). As repetições [GATA $]_{\mathrm{n}}$ se apresentaram dispersas no genoma da espécie, com preferencial localização na região terminal de todos os cromossomos. Os dados aqui obtidos são discutidos com os de outras espécies de Auchenipteridae, especialmente de G. ribeiroi anteriormente analisados do rio Iguaçu. Diferenças populacionais são constatadas em decorrência do isolamento geográfico ocasionado pelas inúmeras cachoeiras existentes no curso do rio Iguaçu.
\end{abstract}

Palavras-chave: barreiras geográficas, DNA ribossomal, Glanidium ribeiroi, rio Iguaçu. 


\section{Introduction}

Among the Siluriforms, Auchenipteridae comprises a group of endemic fish to the Neotropical region. This family comprises about 90 species distributed in 20 genera (Ferraris Junior, 2007), of which 74 have already been registered in Brazil (Akama and Sarmento-Soares, 2007). According to Ferraris Junior (2003), Auchenipteridae is divided into two subfamilies, Centromochlinae and Auchenipterinae. Most of the genera belong to the subfamily Auchenipteridae, with only Centromochlus, Gelanoglanis, Tatia and Glanidium allocated to Centromochlinae (Soares-Porto, 1998). The subfamily Centromochlinae has 31 valid species. Seven of these species belong to the genus Glanidium (Ferraris Junior, 2007). Although G. ribeiroi was recently considered endemic to the Iguazu river basin (Ferraris Junior, 2007), according to Akama and Sarmento-Soares (2007), this species can be found in other rivers in the Paraná basin, in the states of Paraná and São Paulo.

The Iguazu river basin is characterized by a high endemism that is mainly a result of the appearance of the Iguazu Falls (72 meters) in the final stretch of its course, an event which occurred approximately 22 million years ago (Agostinho et al., 2004). According to Zawadzki et al. (1999), the fish fauna endemic to this basin can reach $75 \%$. Besides this large geographic barrier (Iguazu Falls) that separates Iguazu Falls from the Paraná river, other barriers that segment the Iguazu river were reported as follows: Salto Caiacanga (9 meters), Salto Grande (13 meters), Salto Santiago (40 meters) and Salto Osório (30 meters) (Maack, 1981); they act as biogeographical barriers, causing fragmentation of the populations. However, this reality has been changing over the last decades, because most of the waterfalls of the Iguazu river were flooded due to the construction of dams/reservoirs for hydroelectric generation (Julio Junior et al., 1997) (see Figure 1).

Ingenito et al. (2004) reported 81 valid species in this watershed, and when compared to other tributaries of the Paraná basin, the Iguazu has a low number of species (Julio Junior et al., 1997). The chromosomal studies related to the Iguazu river basin include 24 nominally valid species, and at least 10 others that had not yet been described (Kantek et al., 2007). Regarding Auchenipteridae, the chromosomal studies are still scarce, comprising only species of the genera Ageneiosus, Auchenipterus, Glanidium, Parauchenipterus and Tatia (Fenocchio and Bertollo, 1992; Ravedutti and Júlio Junior, 2001; Fenocchio et al., 2008; Lui et al., 2009, 2010, 2013a, b). Regarding the Iguazu river, there are only two valid species of this family, Tatia jaracatia (Pavanelli and Bifi, 2009) and Glanidium ribeiroi, both having 58 chromosomes. T. jaracatia has recently been studied (Lui et al., 2013b), while G. ribeiroi presents studies of other populations within the Iguazu river basin (Ravedutti and Júlio Junior, 2001; Fenocchio et al., 2008).

This study aimed to analyze chromosomally a population of Glanidium ribeiroi, not previously studied, from the final stretch of the Iguazu river; findings were compared with data from three other populations of this species, belonging to three other sections/segments of the Iguazu river, in an attempt to verify the degree of chromosomal variability among populations.

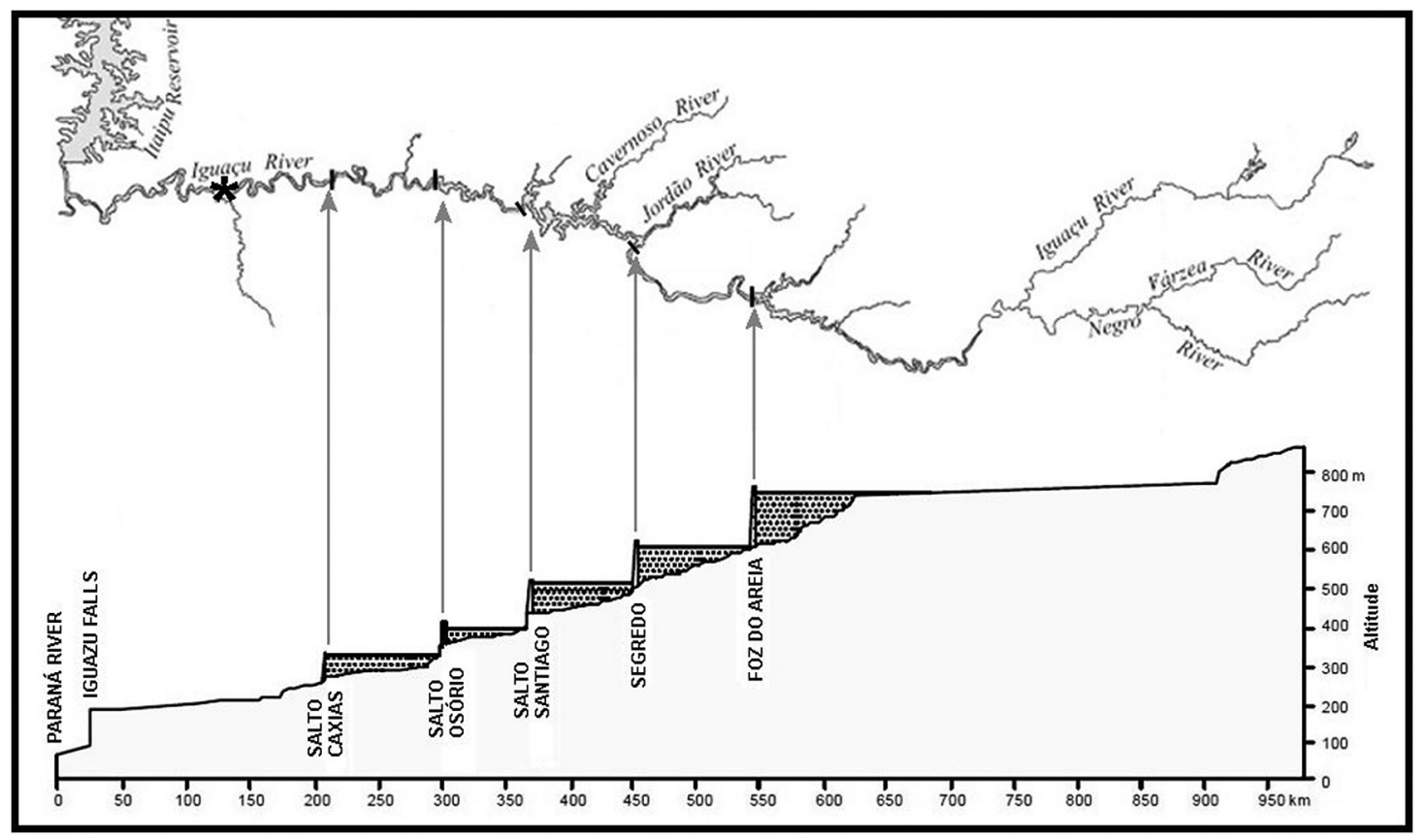

Figure 1. Map and longitudinal profile of the Iguazu river basin, showing its points of impoundment and its rugged topography. The collection point of specimens of Glanidium ribeiroi for this paper is shown with an asterisk. Modified from Júlio Junior et al. (1997) and Daga and Gubiani (2012). 


\section{Material and Methods}

Chromosomal analysis was performed in 43 specimens (20 males and 23 females) of Glanidium ribeiroi from the Iguazu river basin, municipality of Capanema PR (25 $35^{\prime} 19.6^{\prime \prime} \mathrm{S}$; $53^{\circ}$ 54' 48.2” W) (see Figure 1). The specimens were deposited in the fish collection of the Museum of Zoology of the University of São Paulo, and were cataloged (MZUSP 109797). The preparation of cell suspensions of mitotic chromosomes was obtained from the anterior kidney cells (Foresti et al., 1993). The fundamental number (FN) was calculated considering metacentric (m), submetacentric ( $\mathrm{sm}$ ) and subtelocentric (st) chromosomes as having two arms, and acrocentric (a) chromosomes as having only one arm. The heterochromatic pattern was determined by Sumner (1972), with modifications (Lui et al., 2012a) in slides previously analyzed with Giemsa staining (sequential analysis). The Ag-NORs were identified using impregnation by silver nitrate (Howell and Black, 1980), and this preparation was performed on metaphases previously stained by Giemsa and C-banded (sequential analysis).

The fluorescence in situ hybridization (FISH) was performed according to Pinkel et al. (1986), using 18S rDNA (Hatanaka and Galetti Junior, 2004), 5S rDNA (Martins et al., 2000), [TTAGGG] $]_{\mathrm{n}}$ and [GATA $]_{\mathrm{n}}$ probes, which were amplified without template DNA through PCR reaction, as described by Ijdo et al. (1991). The $18 \mathrm{~S}$ rDNA probe was labeled with biotin-16-dUTP by nick translation according to the manufacturer's instruction (Biotin Nick Translation mix - Roche). The 5S rDNA probe was labeled with digoxigenin-11-dUTP by nick translation according to the manufacturer's instruction (Dig 11 Nick Translation mix - Roche). The $[\text { TTAGGG }]_{n}$ and $[\text { GATA }]_{n}$ sequences were labeled by Polymerase Chain Reaction (PCR), using biotin-16-dUTP and digoxigenin-11-dUTP respectively. All the hybridizations were performed with $77 \%$ stringency (200 ng from each probe, $50 \%$ deionized formamide, $10 \%$ dextran sulphate, $2 \mathrm{xSSC} ; \mathrm{pH}$ 7.0-7.2). The chromosomes were analyzed using an Olympus BX51 epifluorescence microscope. The software DP2-BSW (Olympus) was used for image capture.

\section{Results}

The diploid number found for $G$. ribeiroi was 58 chromosomes $(22 \mathrm{~m}+20 \mathrm{sm}+10 \mathrm{st}+6 \mathrm{a}, \mathrm{NF}=110)$ (see Figure 2a). The heterochromatin was located in the terminal regions of several labeled pale chromosomes. In addition, a conspicuous labeled block corresponding to Ag-NORs, and one adjacent to this same site were observed (see Figure 2b). The impregnation by silver nitrate showed only the submetacentric pair 14 marked on the short arm in an interstitial position (see Figure 2, in box). The FISH with the $18 \mathrm{~S}$ rDNA probe showed that only the submetacentric pair 14 was marked on the short arm in interstitial position. The 5S rDNA was observed in interstitial portion of the long arm of the metacentric pair 16 (see Figure 3a). The FISH with telomeric probe

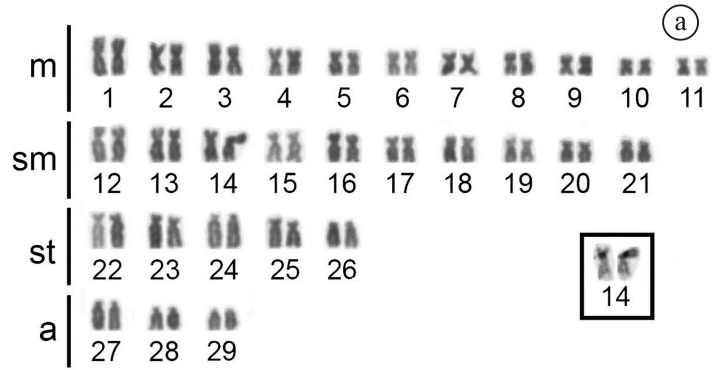

(b)

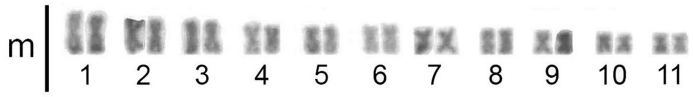

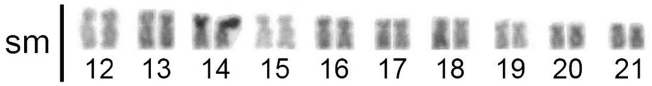

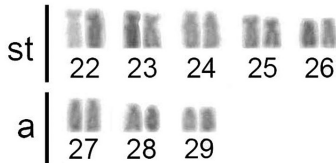

Figure 2. Karyotype of Glanidium ribeiroi of the Iguazu river (final stretch of the basin, municipality of Capanema - PR) stained with Giemsa (a) and C-banded (b). Ag-NORs are presented in the box.

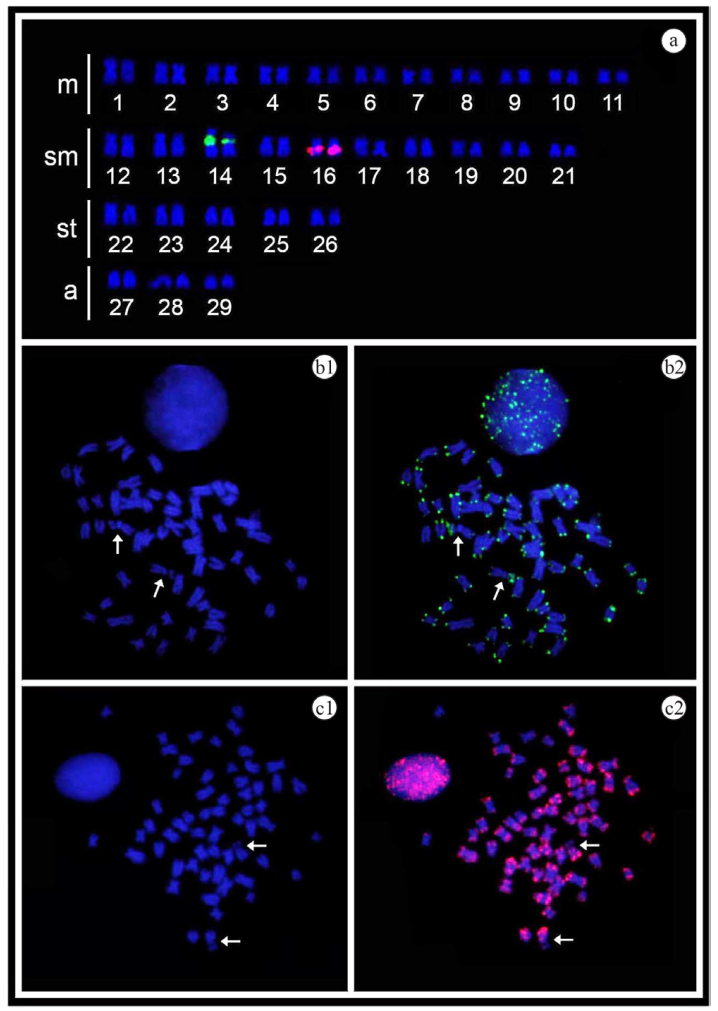

Figure 3. Karyotype of Glanidium ribeiroi of the Iguazu river hybridized with $18 \mathrm{~S}$ rDNA (FITC, green probe) and 5S (Rhodamine, red probe). Metaphases of Glanidium ribeiroi hybridized with telomeric sequence [TTAGGG] (b1 and b2) and [GATA $]_{\mathrm{n}}$ repetitions ( 1 and $\mathrm{c} 2$ ). 
[TTAGGG] showed all telomeres hybridized as expected, with no ITS (Interstitial Telomeric Sequence), and a more prominent hybridization signal in the terminal region of the short arm of pair 14, adjacent to the NOR (see Figure 3b1, 3b2). The hybridization with the repetitive $[\mathrm{GATA}]_{\mathrm{n}}$ sequence shows that this marker is dispersed throughout the genome, with a preferential location in the terminal region of the chromosomes; however, a lesser amount was also observed in the interstitial chromosomal regions (see Figure 3c1, 3c2).

\section{Discussion}

The few chromosomal studies in Auchenipteridae suggest that the diploid number equal 58 chromosomes is a characteristic of this family (Ravedutti and Julio Junior, 2001). Except for the Ageneiosus species, the other genera with cytogenetic analyses (Auchenipterus, Glanidium, Parauchenipterus and Tatia) also show this conserved pattern of the diploid number 58. The sister-group of Auchenipteridae is the Doradidae family (Pinna, 1998), which presents a basal diploid number equal to 58 chromosomes (Eler et al., 2007; Milhomem et al., 2008), the same that is considered basal for Auchenipteridae (Lui et al., 2013a). This same diploid number was found for the population of G. ribeiroi in this paper, and for other populations of the same species previously studied (see Table 1) (Ravedutti and Julio Junior, 2001; Fenocchio et al., 2008). The fundamental number of the population this study was 110 , but quite different from the other three populations due to their karyotypic formulas. Examples in which the diploid number is conserved while there are differences in the karyotype formula are very common in Neotropical fish, for example, in H. malabaricus Bloch, 1794 (Erythrinidae) (Blanco et al., 2010); Pimelodus maculatus Lacepède, 1803 (Pimelodidae) (Mazzuchelli et al., 2007) and Hypostomus spp. (Loricariidae) (Bueno et al., 2012). Rearrangements like translocations and/or pericentric inversions are normally considered responsible for these inter-population differences. This fact is reinforced by FISH with the $[\mathrm{TTAGGG}]_{\mathrm{n}}$ telomeric sequence in this study, which did not show any ITS, a fact that confirms the proposition that non-Robertsonian rearrangements are more closely related to the karyotypic evolution of this species. The non-detection of ITS does not confirm the absence of Robertsonian rearrangements, because an event of fusion need not necessarily result in a chromosome that presents remnants of the telomeric sequence in the interstitial chromosome region (Slijepcevic, 1998). However, this is an aspect that reinforces what already may be suggested with regard to the conservation in the diploid number accompanied by variation in the karyotypic formula in G. ribeiroi.

Most species of Auchenipteridae, analyzed by C-banding of genera Ageneiosus, Auchenipterus, Glanidium, Parauchenipterus and Tatia (Ravedutti and Júlio Junior, 2001; Fenocchio et al., 2008; Lui et al., 2009, 2010, 2013a, b; present paper), presented the heterochromatin as preferentially located in terminal regions with pale blocks, which seems to be a characteristic of the family. One prominent heterochromatic block was observed in the short arm of the pair where the NORs are located in the species of this study. The population of the Salto Caxias reservoir (Ravedutti and Júlio Junior, 2001) also presented this heterochromatic block interspersed with NORs. The other two populations (Salto Segredo and Salto Osório reservoirs) (Fenocchio et al., 2008) did not present this site as positive for C-banding. Thus, differences in the pattern of C-banding related to the short arm of the NORs bearing pair can be detected among the populations.

In the population this paper, the impregnation by silver nitrate showed only a submetacentric pair marked on the short arm in an interstitial position (pair 14), as confirmed by FISH with $18 \mathrm{~S}$ rDNA probe. In the other three populations of G. ribeiroi, a submetacentric pair bearing the NORs was observed; however, small variations in its location on the karyotype can be seen among the three. There are two interesting factors related to the pair carrier of the NOR, regarding the hybridization with the telomeric sequence $[\mathrm{TTAGGG}]_{\mathrm{n}}$ and the repetitive $[\mathrm{GATA}]_{\mathrm{n}}$ sequence. The highest hybridization signal with

Table 1. Cytogenetic data of different populations of Glanidium ribeiroi of the Iguazu river.

\begin{tabular}{|c|c|c|c|c|c|c|c|c|}
\hline Locality & $2 n$ & FN & $\begin{array}{c}\text { Karyotype } \\
\text { formula }\end{array}$ & $\begin{array}{l}\text { Ag-RONs/ } \\
18 S \text { rDNA }\end{array}$ & 5S rDNA & {$[$ TTAGGG] } & {$[\text { GATA }]_{n}$} & Ref. \\
\hline $\begin{array}{l}\text { Reservoir of Segredo, } \\
\text { PR, Brazil }\end{array}$ & 58 & 106 & $\begin{array}{c}22 \mathrm{~m}+16 \mathrm{sm}+ \\
10 \mathrm{st}+10 \mathrm{a}\end{array}$ & $\begin{array}{l}\mathrm{s}, \mathrm{p}, \text { pair } 13, \\
\text { sm }\end{array}$ & - & - & - & 1 \\
\hline $\begin{array}{l}\text { Reservoir of Salto } \\
\text { Osório, PR, Brazil }\end{array}$ & 58 & 106 & $\begin{array}{c}22 \mathrm{~m}+16 \mathrm{sm}+ \\
10 \mathrm{st}+10 \mathrm{a}\end{array}$ & $\begin{array}{l}\text { s, p, pair } 13, \\
\text { sm }\end{array}$ & - & - & - & 1 \\
\hline $\begin{array}{l}\text { Reservoir of Salto } \\
\text { Caxias, PR, Brazil }\end{array}$ & 58 & 112 & $\begin{array}{c}28 \mathrm{~m}+16 \mathrm{sm}+ \\
10 \mathrm{st}+4 \mathrm{a}\end{array}$ & $\begin{array}{l}\text { s, p, pair } 17, \\
\text { sm }\end{array}$ & - & - & - & 2 \\
\hline $\begin{array}{l}\text { Iguazu river, } \\
\text { municipality of } \\
\text { Capanema, PR, Brazil }\end{array}$ & 58 & 110 & $\begin{array}{c}22 \mathrm{~m}+20 \mathrm{sm}+ \\
10 \mathrm{st}+6 \mathrm{a}\end{array}$ & $\begin{array}{l}\text { s, p, pair } 14, \\
\text { sm }\end{array}$ & $\begin{array}{l}\text { s, q, pair } \\
16, \text { sm }\end{array}$ & $\begin{array}{l}\text { Telomeres } \\
\text { marked, no } \\
\quad \text { ITS }\end{array}$ & $\begin{array}{c}\text { Disperse } \\
\text { coincident } \\
\text { with terminal } \\
\text { heterochromatin }\end{array}$ & 3 \\
\hline
\end{tabular}

$\mathrm{PR}=$ State of Paraná; $2 \mathrm{n}=$ diploid number; $\mathrm{FN}=$ fundamental number; $\mathrm{s}=$ single; $\mathrm{p}=$ short arm; $\mathrm{q}=$ long arm; sm = submetacentric. References: 1) Fenocchio et al. (2008); 2) Ravedutti and Júlio Junior (2001); 3) Present study. 
the $[\text { TTAGGG }]_{n}$ probe is in the terminal region of the short arm adjacent to the site of $18 \mathrm{~S}$ rDNA. Amplification of the telomeres adjacent to NORs should have the function of increasing the protection and stability of these regions of ribosomal DNA, since these genes are essential for the cellular maintenance. Regarding the $[\mathrm{GATA}]_{\mathrm{n}}$ repetitions, the pair 14 showed the terminal region on the long arm (strong signal) and proximal to the centromere labeled; however, in the short arm, where the NORs are located in interstitial position, it was not possible to visualize the hybridization signal.

The repetitive element $[\mathrm{GATA}]_{\mathrm{n}}$ is conserved in different animal species, including humans (Subramanian et al., 2003; Srivastava et al., 2008). This sequence appears to be associated with the determining and evolution of sex chromosomes in groups of snakes (Jones and Singh, 1985); however, to date, there are not differentiated sex chromosomes described in Auchenipteridae. Nevertheless, $[\text { GATA }]_{\mathrm{n}}$ is highly dispersed throughout the genome of G. ribeiroi, as shown in this paper. This same situation is found on the genome of another species of Auchenipteridae, A. inermis Linnaeus, 1766 (Lui et al., 2013a). The location of the $[\mathrm{GATA}]_{\mathrm{n}}$ sequence in G. ribeiroi corresponded to the pallid heterochromatin in the terminal region of almost all chromosomes, also occurring in a lesser amount in the interstitial regions (Figure 3c1,3c2). According to Subramanian et al. (2003), this sequence might be related to various functions in the human genome, including gene regulation. In addition, it is concurrently found in the region of the $\mathrm{Y}$ chromosome where the genes of sex determination are, being suggested that this sequence can also be functionally related. Little can be said about the dispersed location in the genome of G. ribeiroi; however, the $[\mathrm{GATA}]_{\mathrm{n}}$ repeats can be a simple repetitive sequence that is part of the heterochromatin structure of this species, or, hypothetically, be related to the regulatory functions, as has already been established previously for humans.

The physical mapping of $5 \mathrm{~S}$ rDNA for Auchenipteridae is rarer than 18S rDNA. Parauchenipterus galeatus Linnaeus, 1766 (Lui et al., 2010), Tatia jaracatia and Tatia neivai Ihering, 1930 (Lui et al., 2013b) present 5S rDNA in more than one pair, which is different to $A$. inermis, which showed only one pair marked (Lui et al., 2013a). Comparing the submetacentric pair 16 (bearing 5S rDNA) of G. ribeiroi with the other species of Auchenipteridae, it is possible to find one correspondent pair on the genome of P. galeatus, T. jaracatia and T. neivai, considering interstitial location on the long arm and submetacentric morphology of the bearing pair. However, this correspondence cannot be established with $A$. inermis, due to the different morphology of the $5 \mathrm{~S}$ rDNA-bearing pair.

The isolation of freshwater fish in their watersheds approaches relationships among the natural histories of ichthyofauna with the basins in which they belong. The changes that occur in basins and their tributaries, as a result of natural events or anthropogenic actions, influence the entire ecosystem, thus giving distinctive characteristics to the natural history of populations that exist within it.
According to Castro (1999), most species of small fish have a relatively restricted ability to dislocate within large river basins. Thus, over the millions of years during the evolution of Neotropical fish, large numbers of geographical and geological changes occurred in water systems, generating numerous examples of vicariance, and creating isolated populations with extremely restricted or non-existent gene flow among them. In a species of Auchenipteridae with a wide distribution in South American watersheds, P. galeatus, these same types of differences were detected and were important to investigate the biogeographical relationships of populations relative to a region of transposition on the river. The inferences elaborated through chromosomal data (Lui et al., 2010) were corroborated by molecular analysis of mitochondrial DNA (Lui et al., 2012b). The chromosomal data of G. ribeiroi in this study, when compared with previous papers (see Table 1), presents a similar situation regarding $P$. galeatus populations; however, it is noteworthy to mention that with G. ribeiroi, all populations exist in the same river.

Studies of several fish species of the Iguazu river basin show a high genetic variability among natural populations of the same species (Agostinho et al., 1999), which reinforces the importance of chromosomal data of G. ribeiroi. Other species from the Iguazu river also have similar data that suggest fragmentation of populations, like Astyanax altiparanae Garutti \& Britski, 2000, Oligosarcus longirostris Menezes \& Géry, 1983, Corydoras paleatus Jenyns, 1842 and Pimelodus ortomanni Haseman, 1911, among others (Kantek et al., 2007), the reason being that, for the most part, this data were obtained after the construction of dams in the Iguazu river. Regarding G. ribeiroi, existing data was collected from most parts of the Iguazu river, comprising the majority of the course with dams (Suzuki, 1999; Cassemiro et al., 2005; Agostinho et al., 2007), with exception to some rivers of high Iguazu (Ingenito et al., 2004). Despite the fact that some barriers have ceased to exist in recent history due to the construction of a series of hydroelectric dams (after 1975), it is very likely that population fragmentations may be a consequence of the series of waterfalls that existed previously on the Iguazu river.

This reveals that each population of the ichthyofauna of the Iguazu river represents a diversified genetic heritage that must be conserved. For example, on the Segredo reservoir alone, more than fifteen species were considered at risk of extinction (Agostinho et al., 1999). Due to the recent growth urban around this basin, conservation programs and management of the ichthyofauna of the Iguazu river are of great importance, not only for the high endemism at interspecific level, but also by genetic heritage unique at intraspecific level, in that local extinctions may lead to loss of genetic variability.

\section{Acknowledgements}

The authors are grateful to Dr. Heraldo Antonio Britski for the identification of the specimens; the laboratory technician Pedro Luis Gallo and the GETECH (Grupo 
de Pesquisa em Tecnologia de Produção e Conservação de Recursos Pesqueiros e Hídricos of UNIOESTE) for assistance with the samplings; the Instituto Brasileiro do Meio Ambiente e dos Recursos Naturais Renováveis (IBAMA) for the authorization for the material collection. This study was financed by Fundação de Amparo à Pesquisa do Estado de São Paulo (FAPESP), by Conselho Nacional de Desenvolvimento Científico e Tecnológico (CNPq) and by Coordenação de Aperfeiçoamento de Pessoal de Nível Superior (CAPES).

\section{References}

AGOSTINHO, A.A., GOMES, L.C. and PELICICE, F.M., 2007. Ecologia e manejo de recursos pesqueiros em reservatórios do Brasil. Maringá: Eduem.

AGOSTINHO, A.A., GOMES, L.C., SUZUKI, H.I. and JÚLIO JUNIOR, H.F., 1999. Riscos da implantação de cultivos de espécies exóticas em tanques-redes em reservatórios do rio Iguaçu. Cadernos da Biodiversidade, vol. 2, no. 2, pp. 1-9.

AGOSTINHO, A.A., GOMES, L.C., SUZUKI, H.I. and JÚLIO JUNIOR, H.F., 2004. Migratory fishes of the Upper Paraná River Basin, Brazil. In: J. CAROLSFELD, B. HARVEY, C. ROSS and A. BAER. Migratory fishes of South America: biology, fisheries and conservation status. Victoria: IDRC Publications, pp. 19-98.

AKAMA, A. and SARMENTO-SOARES, L.M., 2007. Família Auchenipteridae. In: P.A. BUCKUP, N.A. MENEZES and M.S. GHAZZI. Catálogo das espécies de peixes de água doce do Brasil. Rio de Janeiro: Museu Nacional/Universidade Federal do Rio de Janeiro, pp. 116-120. Série Livros, no. 23.

BLANCO, D.R., LUI, R.L., BERTOLLO, L.A.C., MARGARIDO, V.P. and MOREIRA-FILHO, O., 2010. Karyotypic diversity between allopatric populations of the group Hoplias malabaricus (Characiformes: Erythrinidae): evolutionary and biogeographic considerations. Neotropical Ichthyology, vol. 8, no. 2, pp. 361-368. http://dx.doi.org/10.1590/S1679-62252010000200015.

BUENO, V., ZAWADZKI, C.H. and MARGARIDO, V.P., 2012. Trends in chromosome evolution in the genus Hypostomus Lacépède, 1803 (Osteichthyes, Loricariidae): a new perspective about the correlation between diploid number and chromosome types. Reviews in Fish Biology and Fisheries, vol. 22, no. 1, pp. 241-250. http://dx.doi.org/10.1007/s11160-011-9215-9.

CASSEMIRO, F.A.S., HAHN, N.S. and DELARIVA, R.L., 2005. Estrutura trófica da ictiofauna, ao longo do gradiente longitudinal do reservatório de Salto Caxias (rio Iguaçu, Paraná, Brasil), no terceiro ano após o represamento. Acta Scientiarum: Biological Sciences, vol. 27, no. 1, pp. 63-71.

CASTRO, R.M.C., 1999. Evolução da ictiofauna de riachos sul-americanos: padrões gerais e possíveis processos casuais. In: E.P. CARAMASCHI, R. MAZZONI, C.R.S.F. BIZERRIL and P.R. PERES-NETO, eds. Ecologia de peixes de riachos: estado atual e perspectivas. Rio de Janeiro: Oecologia Brasiliensis, pp. 139-155, no. 6.

DAGA, V.S. and GUBIANI, E.A., 2012. Variations in the endemic fish assemblage of a global freshwater ecoregion: associations with introduced species in cascading reservoirs. Acta Oecologica, vol. 41, pp. 95-105. http://dx.doi.org/10.1016/j.actao.2012.04.005.

ELER, E.S., DERGAM, J.A., VENERE, P.C., PAIVA, L.C., MIRANDA, G.A. and OLIVEIRA, A., 2007. The karyotypes of the thorny catfishes Wertheimeria maculata Steindachner, 1877 and Hassar wilderi Kindle, 1895 (Siluriformes: Doradidae) and their relevance in doradids chromosomal evolution. Genetica, vol. 130, no. 1, pp. 99-103. http://dx.doi.org/10.1007/s10709006-0023-4. PMid:16897457.

FENOCCHIO, A.S. and BERTOLLO, L.A.C., 1992. Karyotype, C-bands and NORs of the neotropical siluriform fish Ageneiosus brevifilis and Ageneiosus atronases (Ageneiosidae). Cytobios, vol. 72 , pp. 19-22.

FENOCCHIO, A.S., DIAS, A.L., MARGARIDO, V.P. and SWARÇA, A.C., 2008. Molecular cytogenetic characterization of Glanidium ribeiroi (Siluriformes) endemic to the Iguaçu river, Brazil. Chromosome Science, vol. 11, pp. 61-66.

FERRARIS JUNIOR, C.J., 2007. Checklist of catfishes, recent and fossil (Osteichthyes: Siluriformes), and catalogue of siluriform primary types. Zootaxa, vol. 1418, pp. 1-628.

FERRARIS JUNIOR, C.J., 2003. Family Auchenipteridae. In: R.E. REIS, S.O. KULLANDER and C.J. FERRARIS JUNIOR. Check list of freshwater fishes of South and Central America. Porto Alegre: EdiPUCRS, pp. 470-482.

FORESTI, F., OLIVEIRA, O. and ALMEIDA-TOLEDO, L.F., 1993. A method for chromosome preparations from large fish specimens using in vitro short-term treatment with colchicine. Experientia, vol. 49, no. 9, pp. 810-813. http://dx.doi.org/10.1007/ BF01923555.

HATANAKA, T. and GALETTI JUNIOR, P.M., 2004. Mapping of the 18S and 5S ribosomal RNA genes in the fish Prochilodus argenteus Agassiz, 1829 (Characiformes, Prochilodontidae). Genetica, vol. 122, no. 3, pp. 239-244. http://dx.doi.org/10.1007/ s10709-004-2039-y. PMid:15609546.

HOWELL, W.M. and BLACK, D.A., 1980. Controlled silver staining of nucleolus organizer regions with a protective colloidal developer: a 1-step method. Experientia, vol. 36, no. 8, pp. 10141015. http://dx.doi.org/10.1007/BF01953855. PMid:6160049.

IJDO, J.W., WELLS, R.A., BALDINI, A. and REEDERS, S.T., 1991. Improved telomere detection using a telomere repeat probe (TTAGGG) $)_{\mathrm{n}}$ generated by PCR. Nucleic Acids Research, vol. 19, no. 17, pp. 4780. http://dx.doi.org/10.1093/nar/19.17.4780. PMid:1891373.

INGENITO, L.F.S., DUBOC, L.F. and ABILHOA, L.F., 2004. Contribution to the knowledge of the ichthyofauna from the upper Iguaçu river basin, Paraná, Brazil. Arquivos de Ciências Veterinárias e Zoologia da UNIPAR, vol. 7, pp. 23-36.

JONES, K.W. and SINGH, L., 1985. Snakes and the evolution of sex chromosomes. Trends in Genetics, vol. 1, pp. 55-61. http:// dx.doi.org/10.1016/0168-9525(85)90024-1.

JÚLIO JUNIOR, H.F., BONECKER, C.C. and AGOSTINHO, A.A., 1997. Reservatório de Segredo e sua inserção na bacia do Rio Iguaçu. In: A.A. AGOSTINHO and L.C. GOMES. Reservatório de Segredo: bases ecológicas para o manejo. Maringá: Eduem, pp. 1-17.

KANTEK, D.L.Z., CIPRIANO, R.R., ABILHOA, V., ARTONI, R.F. and CESTARI, M.M., 2007. Cytotaxonomic and evolutionary considerations about karyotipic data of fishes from the Iguaçu river basin in south of Brazil. Brazilian Archives of Biology and Technology, vol. 50, no. 5, pp. 793-802. http://dx.doi.org/10.1590/ S1516-89132007000500007.

LUI, R.L., BLANCO, D.R., MARGARIDO, V.P. and MOREIRAFILHO, O., 2009. First description of B chromosomes in the 
family Auchenipteridae, Parauchenipterus galeatus (Siluriformes) of the São Francisco River basin (MG, Brazil). Micron (Oxford, England), vol. 40, no. 5-6, pp. 552-559. http://dx.doi.org/10.1016/j. micron.2009.03.004. PMid:19394233.

LUI, R.L., BLANCO, D.R., MARGARIDO, V.P. and MOREIRAFILHO, O., 2010. Chromosome characterization and biogeographic relations among three populations of the driftwood catfish Parauchenipterus galaetus (Linnaeus, 1766) (Siluriformes: Auchenipteridae) in Brazil. Biological Journal of the Linnean Society. Linnean Society of London, vol. 99, no. 3, pp. 648-656. http://dx.doi.org/10.1111/j.1095-8312.2009.01389.x.

LUI, R.L., BLANCO, D.R., MOREIRA-FILHO, O. and MARGARIDO, V.P., 2012a. Propidium iodide for making heterochromatin more evident in the C-banding technique. Biotechnic \& Histochemistry, vol. 87, no. 7, pp. 433-438. http://dx.doi.org/10.3109/10520295. 2012.696700. PMid:22747174.

LUI, R.L., BLANCO, D.R., MARGARIDO, V.P., KUHN, G.C.S., GOMES, V.N., PRIOLI, A.J. and MOREIRA-FILHO, O., 2012b. A recent transposition of river involving Paraná and São Francisco basins: effects on the genetic variability and structure of the neotropical fish Parauchenipterus galeatus (Siluriformes, Auchenipteridae). Mitochondrial DNA, vol. 23, no. 5, pp. 388-395. http://dx.doi.org/10.3109/19401736.2012.690747. PMid:22803711.

LUI, R.L., BLANCO, D.R., MARTINEZ, J.F., MARGARIDO, V.P., VENERE, P.C. and MOREIRA-FILHO, O., 2013a. The role of chromosomal fusion in the karyotypic evolution of the genus Ageneiosus (Siluriformes, Auchenipteridae). Neotropical Ichthyology, vol. 11, no. 2, pp. 327-334. http://dx.doi.org/10.1590/ S1679-62252013005000004.

LUI, R.L., BLANCO, D.R., MARGARIDO, V.P., TROY, W.P. and MOREIRA-FILHO, O., 2013b. Comparative chromosomal analysis and evolutionary considerations concerning two species of genus Tatia (Siluriformes, Auchenipteridae). Comparative Cytogenetics, vol. 7, no. 1, pp. 63-71. http://dx.doi.org/10.3897/ compcytogen.v7i1.4368. PMid:24260691.

MAACK, R., 1981. Geografia fisica do Estado do Paraná. 2nd ed. Rio de Janeiro: José Olympio/Secretaria da Cultura e do Esporte do Estado do Paraná.

MARTINS, C., WASKO, A.P., OLIVEIRA, C. and WRIGHT, J.M., 2000. Nucleotide sequence of 5S rDNA and localization of the ribosomal RNA genes to metaphase chromosomes of the Tilapiine cichlid fish, Oreochromis niloticus. Chromosome Research, vol. 133, no. 1, pp. 39-46. PMid:11206852.

MAZZUCHELLI, J., SWARÇA, A.C. and DIAS, A.L., 2007. Structural chromosome polymorphism in a Pimelodus maculatus La Cepède, 1803 Population (Siluriformes, Pimelodidae) from the Paranapanema River Basin, PR. Brazilian Journal of Biology = Revista Brasileira de Biologia, vol. 67, no. 4, suppl., pp. 935937. http://dx.doi.org/10.1590/S1519-69842007000500018. PMid:18278362.

MILHOMEM, S.S.R., SOUZA, A.C.P., NASCIMENTO, A.L., CARVALHO JUNIOR, J.R., FELDBERG, E., PIECZARKA, J.C. and NAGAMACHI, C.Y., 2008. Cytogenetic studies in fishes of the genera Hassar, Platydoras and Opsodoras (Doradidae, Siluriformes) from Jarí and Xingú rivers, Brazil. Genetics and Molecular Biology, vol. 31, no. 1, pp. 256-260. http://dx.doi. org/10.1590/S1415-47572008000200017.

PINKEL, D., STRAUME, T. and GRAY, J., 1986. Cytogenetic analysis using quantitative, high-sensitivity, fluorescence hybridization. Proceedings of the National Academy of Sciences of the United States of America, vol. 83, no. 9, pp. 2934-2938. http://dx.doi.org/10.1073/pnas.83.9.2934. PMid:3458254.

PINNA, M.C.C., 1998. Phylogenetics relationships of Neotropical Siluriformes: historical overview and synthesis of hypothesis. In: L.R. MALABARBA, R.E. REIS, R.P. VARI, Z.M.S. LUCENA and C.A.S. LUCENA. Phylogeny and classification of neotropical fishes. Porto Alegre: EdiPUCRS, pp. 279-330.

RAVEDUTTI, C.G. and JÚLIO JUNIOR, H.F., 2001. Cytogenetic analysis of three species of the neotropical Family Auchenipteridae (Pisces, Siluriformes) from the Paraná River Basin, Brazil. Cytologia, vol. 66, no. 1, pp. 65-70. http://dx.doi.org/10.1508/ cytologia.66.65.

SLIJEPCEVIC, P., 1998. Telomeres and mechanisms of Robertsonian fusion. Chromosoma, vol. 107, no. 2, pp. 136-140. http://dx.doi. org/10.1007/s004120050289. PMid:9601982.

SOARES-PORTO, L.M., 1998. Monophyly and interrelationships of the Centromochlinae (Siluriformes: Auchenipteridae). In: L.R. MALABARBA, R.E. REIS, R.P. VARI, Z.M.S. LUCENA and C.A.S. LUCENA. Phylogeny and classification of neotropical fishes. Porto Alegre: EdiPUCRS, pp. 331-350.

SRIVASTAVA, J., PREMI, S., KUMAR, S. and ALI, S., 2008. Organization and differential expression of the GACA/GATA tagged somatic and spermatozoal transcriptomes in Buffalo Bubalus bubalis. BMC Genomics, vol. 9, no. 1, pp. 132. http:// dx.doi.org/10.1186/1471-2164-9-132. PMid:18366692.

SUBRAMANIAN, S., MISHRA, R.K. and SINGH, L., 2003. Genome-wide analysis of $B k m$ sequences (GATA repeats): predominant association with sex chromosomes and potential role in higher order chromatin organization and function. Bioinformatics, vol. 19, no. 6, pp. 681-685. http://dx.doi.org/10.1093/bioinformatics/ btg067. PMid:12691979.

SUMNER, A.T., 1972. A simple technique for demonstrating centromeric heterochromatin. Experimental Cell Research, vol. 75, no. 1, pp. 304-306. http://dx.doi.org/10.1016/00144827(72)90558-7. PMid:4117921.

SUZUKI, H.I., 1999. Estratégias reprodutivas de peixes relacionadas ao sucesso na colonização em dois reservatórios do Rio Iguaçu, $P R$, Brasil. São Carlos: Universidade Federal de São Carlos, 97 p. Masters Dissertation.

ZAWADZKI, C.H., RENESTO, E. and BINI, L.M., 1999. Genetic and morphometric analysis of three species of the genus Hypostomus Lacépède, 1803 (Osteichthyes: Locariidae) from the Rio Iguaçu basin (Brasil). Revue Suisse de Zoologie, vol. 106, pp. 91-105. http://dx.doi.org/10.5962/bhl.part.80072. 